\title{
Effect of Radiotherapy on Oral Microflora of Patients with Head and Neck Malignancies
}

\author{
Jatinder Singh $^{1}$, Prabhjot Kaur Gill ${ }^{2}$, GPI Singh ${ }^{3}$, Inderpreet Kaur ${ }^{4}$ \\ ${ }^{1}$ Prof \& Head, Department of Public Health Dentistry, Adesh Institute of Dental Sciences and Research, Adesh University, Bathinda \\ ${ }^{2}$ Associate Prof, Centre for Interdisciplinary Biomedical Research, Adesh University, Bathinda \\ ${ }^{3}$ Honorable Vice Chancellor, Adesh University, Bathinda
}

${ }^{4}$ Prof \& Head, Department of Prosthodontics, Adesh Institute of Dental Sciences and Research, Adesh University, Bathinda

\begin{abstract}
Globally cancer is a big threat to life of human beings and scientists are researching mechanisms to get rid from this deadly disease. After Human Genome Project now scientists are moving towards the microbiome studies of individuals. The head and neck cancers for which radiotherapy is an effective treatment has resulted in harmful effects of radiation on oral mucosa, dentition, salivary glands, masticatory musculature and most importantly the oral microflora. Basic and clinical data suggest that patients'oral microflora alter after radiotherapy induces diseases like candidasis, dental or radiation caries, mucositis, hyposalivation and xerostomia. The imbalance of natural oral microflora can play an important role in the pathogenesis of head and neck malignancies after radiotherapy. Therefore this review has been written to elaborate the effects of radiation on oral microflora of patients after radiotherapy, so that timely treatment planning and preventive measures are undertaken to avoid complications.
\end{abstract}

Key words: cancer, dentition, mucositis, microflora, radiotherapy

\section{Introduction}

Malignancies of head and neck constitute a large percentage of cancer worldwide. Radiotherapy (RT) alone or associated with surgery or chemotherapy, has produced a significant increase in cure rates for many malignancies of the head and neck region. In comparison with surgical procedures, radiotherapy can be used as a curative, adjuvant, neoadjuvant and palliative type of treatment and is often used in conservative approaches, with protocols that preserve organs and tissues (Marta et al. 2014; de Barros da Cunha et al. 2015). Chemotherapy has also been used as complement of this treatment, because it is considered as less disfiguring and disabling, but radiation therapy is usually the more desirable modality for treatment of head and neck cancers, provided of course that there is a choice of therapy (Kamath et al. 2002). Unfortunately, apart from the target tumor, ionizing radiation also affects the healthy tissue surrounding the target, resulting in serious side effects and an overall decrease in the patients' quality of life (Baskar et al. 2014). Among all malignancies, head and neck malignancy is often associated with compromised immunity which is further compromised with radiotherapy leading to xerostomia, stomatitis, oral mucositis, dental caries, accelerated periodontal disease, fibrosis, photosensitivity, taste loss, oral infection, trismus, radiation dermatitis, soft tissue necrosis, and osteoradionecrosis (Agarwal et al. 2012). Delayed wound healing of soft tissue and bone wounds after radiation therapy can cause major clinical problems even years after radiation therapy (Baskar et al. 2014). The occurrence and severity of these reactions depend on the radiation dose, volume of irradiated tissues, fractionation scheme, type of ionizing radiation, location of the irradiated area, patient's age, systemic conditions, concomitant treatment, oral hygiene, tobacco and alcohol consumption (Al-Nawas and Grötz, 2006; Baskar et al. 2014). In patients subjected to radiotherapy, radiation has destructive effect on the salivary glands and often leads to hyposalivation (reduced salivary flow) and xerostomia (dry mouth syndrome). This interruption of the salivary flow and associated xerostomia following radiation therapy has previously been linked with shifts in the oral Microbiome. Traditionally it has been thought that oral mucosa, tongue and pharynx harbor characteristic bacterial pathogens causing chronic inflammation and focal infections (Möller et al. 2004; Ray-Chaudhuri et al. 2013). Many of these infections derived from oral biofilms are commonly linked with the highly prevalent dental diseases (Bhatia and Ichhpujani, 1994; Robins-Sadler et al. 2003; Behl et al, 2014). For a long time, particularly periodontal disease has been emphasized in this respect (Brown et al. 1978). It is a well-known clinical fact that the patients with oral cancer often present with poor oral hygiene. In addition to bacterial organisms, oral microorganisms can include fungal, protozoal, and viral species. A variety of organisms in the microenvironment of the oral cavity adhere to the teeth, the gingival sulcus, the tongue, and the buccal mucosa and till now only 22 predominant microflora have been identified (Najjar et al. 2004). Each site has a unique way of allowing the organisms to establish their residency (Keegan, 2007). The normal flora in healthy individuals maintains similar patterns. When a local or systemic disease process or concomitant use of medications alter this overall pattern, atypical organisms begin to predominate and some normal organisms with a benign nature, such as Candida albicans, become pathogenic (Najjar et al. 2004). After radiotherapy oral microflora showed higher abundances of Streptococcus mutans, Lactobacillus spp., Candida and Staphylococcus spp., whereas the number of S. sanguis, Neisseria spp. and Fusobacterium spp. tends to decrease. These microbial changes might trigger other side effects. The overgrowth of potential harmful species such as Candida spp. (mainly C. albicans) or cariogenic species

\section{Volume 6 Issue 12, December 2017}




\section{International Journal of Science and Research (IJSR) \\ ISSN (Online): 2319-7064}

Index Copernicus Value (2016): 79.57 | Impact Factor (2015): 6.391

resulted in higher prevalence of candidiasis and caries in patients treated with radiotherapy (De Ryck et al. 2015).

Therefore, the present review discusses the researches and recent advancement on oral Microflora after radiotherapy of patients with head and neck malignancies.

\section{Radiation therapy and types}

Radiation therapy or Radiotherapy (RT) kills cancer cells by damaging their DNA. It can either damage DNA directly or create charged particles i.e. free radicals within the cells that can in turn damage the DNA. Radiation can damage some types of normal tissue more easily than others. For example, the reproductive organs (testicles and ovaries) are more sensitive to radiation than bones (Ray-Chaudhuri et al.
2013). Radiation doses for cancer treatment are measured in a unit called a Gray (Gy), which is a measure of the amount of radiation energy absorbed by 1 kilogram of human tissue. Different doses of radiation are needed to kill different types of cancer cells (Ray-Chaudhuri et al. 2013) (Table 1). If an area of the body has previously been treated with radiation therapy, a patient may not be able to have radiation therapy to that area a second time, depending upon how much radiation was given during the initial treatment. If one area of the body has already received the maximum safe life time dose of radiation, another area might still be treated with radiation therapy, if the distance between the two areas is large enough. The area selected for treatment usually includes the whole tumor plus a small amount of normal tissue surrounding the tumor.

Table 1: Types of Radiation Therapy for treatment of Head and Neck Malignancies

\begin{tabular}{|c|c|}
\hline External beam radiation therapy & Internal beam radiation therapy \\
\hline $\begin{array}{c}\text { The radiation is delivered by a machine outside the body. This } \\
\text { type of therapy is most often delivered in the form of photon } \\
\text { beams i.e. either x-rays or gamma rays. One of the most } \\
\text { common types of external-beam radiation therapy is called 3- } \\
\text { Dimensional Conformal Radiation Therapy (3D-CRT). }\end{array}$ & $\begin{array}{c}\text { The radiation is delivered from radioactive material placed in the body near } \\
\text { cancer cells, also called as Brachytherapy. Brachytherapy is put in place } \\
\text { through a catheter. Once the catheter or applicator is in place, the radiation } \\
\text { source is placed inside it. The radiation source may be kept in place for a } \\
\text { few minutes, for many days, or for the rest of patient life. }\end{array}$ \\
$\begin{array}{c}\text { This can be done in one of these ways: } \\
\text { 1. Accelerated fractionation, which gives the half of the } \\
\text { usual daily dose of radiation twice each day. }\end{array}$ & $\begin{array}{c}\text { There are three types of Brachytherapy: } \\
\text { 1. Low-Dose Rate (LDR) implants: In this type of Brachytherapy, the } \\
\text { radiation source stays in place for 1 to 7 days. The patient is likely to be in } \\
\text { the hospital during this time. Once the treatment is finished, the doctor will } \\
\text { remove the radiation source and the catheter or applicator. }\end{array}$ \\
$\begin{array}{c}\text { 2. Hyperfractionation, which is a smaller than usual daily } \\
\text { dose of radiation given twice each day. }\end{array}$ & $\begin{array}{c}\text { 2. High-Dose Rate (HDR) implants: In this type of Brachytherapy, the } \\
\text { radiation source is left in place for just 10 to 20 minutes at a time and then } \\
\text { taken out. Patients may have treatment twice a day for 2 to 5 days or once a } \\
\text { week for 2 to 5 weeks. The schedule depends on the type of cancer. }\end{array}$ \\
$\begin{array}{c}\text { 3. Permanent implants: After the radiation source is put in place, the } \\
\text { 3. Hypofractionation, which is a larger than usual daily dose } \\
\text { of radiation given once a day for upto 3 weeks } \\
\text { his life, but the radiation gets weaker each day. As the time goes on, almost } \\
\text { all the radiation will go away. }\end{array}$ \\
\hline
\end{tabular}

\section{Development and Function of Normal Oral Microflora}

The oral cavity of newborn is usually free from microorganisms or colonization begins within a few hours after birth with microorganisms from the mother, nurses and sometimes from the environment (MacFarlane and Samaranayake, 1989). The bacterial colonization started during the first months of life and the oral mucosa surfaces of babies can provide niches for bacterial colonization (Könönen, 2000). There is considerable variability in oral bacteria and both aerobes (McCarthy, 1965) and anaerobes (Brook, 2011) can be detected in the oral cavity after 8 days of birth. The Streptococcus salivarius a pioneer colonizer of the human oral cavity (Rotimi and Duerden, 1981; MacFarlane and Samaranayake, 1989), being detected after $8 \mathrm{~h}$ of birth (Rotimi and Duerden, 1981). During the first year of life, other species of Streptococci, Staphylococci, Neisseriae, Vellonelliae, Actinomyces, Lactobacilli and Fusobacteria also colonise. With the eruption of teeth, solid surfaces in the oral cavity are available for colonization. Streptococcus mutans, Streptococcus sanguis and Actinomyces establish themselves on these hard surfaces (Caufield et al. 2000).
The developing intestinal and oral microbiota plays an important role in the health and well being of the host (Marcotte and Lavoie, 1998). The normal microflora of the oral cavity contains 75 to 100 different microbial species. The normal oral flora occupies available colonization sites which makes it more difficult for other non-indigenous microbial species to become established (Dewhirst et al. 2010). In addition, the oral bacteria exert microbial antagonism against non-indigenous species by production of antimicrobial compounds, which can be classified as lowmolecular-mass (LMM) compounds such as hydrogen peroxide $\left(\mathrm{H}_{2} \mathrm{O}_{2}\right)$, carbon dioxide $\left(\mathrm{CO}_{2}\right)$, diacetyl $(2,3-$ butanedione), uncharacterized compounds, and highmolecular-mass (HMM) compounds like bacteriocins (Aas et al. 2005). Also, the oral flora contributes to host nutrition through the synthesis of vitamins and immunity by inducing low levels of circulating and secretary antibodies that may cross react with pathogens. On the other hand, the normal oral flora can also be the usual cause of various oral diseases in humans - including abscesses (infections), dental caries (cavities), gingivitis (inflammation of the gums) and periodontal disease (gum infection resulting in tooth loss) (Aas et al 2005; Dewhirst et al. 2010). Though the oral cavity is teaming with a variety of microbial species, the more common species which can be both helpful as well as harmful to the host are in the table 2: 
International Journal of Science and Research (IJSR)

ISSN (Online): 2319-7064

Index Copernicus Value (2016): 79.57 | Impact Factor (2015): 6.391

Table 2: Human normal oral microflora and its functions

\begin{tabular}{|c|c|c|}
\hline $\begin{array}{c}\text { Sr. } \\
\text { No. }\end{array}$ & Oral Microorganisms & Functions \\
\hline 1. & Actinomyces naeslundii & Forms dental plaque by adhering to the surface of the teeth. \\
\hline 2. & $\begin{array}{c}\text { Actinobacillus } \\
\text { actinomycetemcomitans }\end{array}$ & Severe infection of the periodontium, although it is also associated with non oral infections \\
\hline 3. & Bacteroide melaninogenicus & causes periodontal disease \\
\hline 4. & Bifidobacterium lactis BB-12 & Modified the protein composition of the salivary pellicle and specifically prevent adhesion of other \\
bacteria, such as $S$. mutans.
\end{tabular}

\section{Changes in Oral Cavity Microflora after Radiotherapy}

Radiotherapy-induced damage is not only in the oral mucosa, salivary glands, bone, dentition, and masticatory musculature, but also has more deleterious effects on the oral microflora (Table 3). Radiotherapy-induced microflora based complications in patients are complex and difficult to handle. Dynamic pathobiological processes lower the quality of life and predispose patients to serious clinical disorders (Stephen et al. 2003). The changes in oral microbial population of the patients leads to severe pain in the oral cavity and these patients are unable to eat solids (Takeshita et al. 2011). Diet and more specifically, the protein and starch content of food influenced the oral microbial abundance of Lactobacilli and Streptococci. After radiotherapy the tube-fed patients showed disruption of indigenous oral microbiota, allowing other opportunistic pathogens like Corynebacterium striatum and Streptococcus agalacticae to grow in large numbers and become predominant species in oral cavity (Takeshita et al. 2011). The Candida albicans is commensal inhabitant of the oral cavity in a large proportion of individuals. Under normal conditions, these fungal organisms co-exist with other microorganisms of the normal oral flora and do not cause any disease. However, cancer patients receiving radiation therapy are prone to higher risk for oral fungal infection, because of imbalance in the oral flora, hyposalivation (secondary to radiotherapy) and local tissue damage (mucositis secondary to radiotherapy) (Lalla et al. 2014). For all cancer treatments, the weighted prevalence of oral colonization of Candida species was $48.2 \%$ before treatment, $72.2 \%$ during treatment and $70.1 \%$ after the treatment. The prevalence of oral fungal colonization during chemotherapy $(72.8 \%)$ was similar to that during radiation therapy $(74.5 \%)$. Different studies reported that Candida albicans prevalence was highest (46\%) during cancer therapy, whereas prevalence rates of Candida tropicalis was
$16.6 \%, 5.5 \%$ for Candida glabrata, and 3\% for Candida krusei (Lalla et al. 2014). Therefore, the low immunity may allow the establishment of opportunist infections, such as candidiasis, a common fungal infection caused by Candida albicans. Gaetti-Jardim et al. 2011 examined saliva, mucosa and biofilm from fifty cancer patients, before radiotherapy, during radiotherapy and 30 days after radiotherapy. Most prevalent microorganisms after radiotherapy based on PCR detection were Candida albicans, $C$. tropicalis, $C$. krusei, $C$. glabrata and $C$. parapsilosis followed by Citrobacter, Enterobacter, Enterococcus, Klebsiella, Proteus, and Pseudomonas. Whereas before radiotherapy, targeted bacteria were cultivated from $22.2 \%$ of edentulous patients and $16.6 \%$ of dentate patients; 30 days after radiotherapy, these microorganisms were recovered from $77.8 \%$ edentulous and $46.8 \%$ dentate patients. Modifications in the oral environment due to radiotherapy treatment seems to facilitate the colonization of oral cavity by members of family Enterobacteriaceae, Enterococcus spp. and Candida spp. Xerostomia or reduced salivation is one of the most frequent effects of radiotherapy in the head and neck region (Emidio et al. 2010). Salivary glands are expected to be relatively radio-resistant due to slow turnover rates of their cells. Yet, quantitative as well as qualitative changes in the saliva may be seen shortly after antineoplastic therapy. Since there is an increase in viscosity and proportion of organic material, the color of the saliva may change from transparent to opaque white or opaque yellow. The $\mathrm{pH}$ and buffering capacity of saliva decreases, and there is alteration in electrolyte levels. The radiation therapy causes fibrosis, degeneration of salivary acinar cells, and necrosis of salivary glands that lead to these changes (Emidio et al. 2010). Due to low $\mathrm{pH}$, the oral flora shows a shift from Gram-positive to Gram-negative bacteria (Mathur et al. 2012). Further, Sonalika (2012) reported that in addition to radiation therapy tobacco chewing habit and presence of squamous cell carcinoma in oral cavity also causes alterations in healthy oral microflora in patients. Abnormal flora developed due to radiotherapy in oral squamous cell carcinoma patients can

\section{Volume 6 Issue 12, December 2017}




\section{International Journal of Science and Research (IJSR) \\ ISSN (Online): 2319-7064}

Index Copernicus Value (2016): 79.57 | Impact Factor (2015): 6.391

exacerbate mucositis and can cause systemic infections. The frequency of isolation of total aerobes and anaerobes, coliforms and gram negative anaerobic bacteria was significantly high in oral squamous cell carcinoma patients compared to healthy controls, whereas Candida sp. was isolated most frequently during radiation period. Similarly, Pushalkar et al. 2012 investigated the association of oral bacteria in oral squamous cell carcinoma tissues and compared it with adjacent non tumour mucosa sampled $5 \mathrm{~cm}$ distant from the same patient. By using culture independent $16 \mathrm{~S}$ rDNA approaches, Denaturing Gradient Gel Electrophoresis, cloning and sequencing, assessed the total bacterial diversity in these clinical samples. Denaturing Gradient Gel Electrophoresis fingerprint showed variations in the band intensity profiles within non-tumour and tumour tissues of the same patient and also among the two groups. The clonal analysis indicated that from a total of 1200 sequences characterised, 80 bacterial species were detected representing 6 phyla-Firmicutes, Bacteriodetes, Proteobacteria, Fusobacteria, Actinobacteria and uncultivated TM7 in non-tumour and tumour libraries. Bacterial species, Streptococcus sp. Oral taxon 058, Peptostreptococcus stomatis, Streptococcus gordonii, Gamella haemolysins, Gamella morbillorum, Johnsonella ignava and Streptococcus parasanguinis were highly associated with tumour site, whereas Granulicatella adiacens was prevalent at non-tumour site. Streptococcus intermedius was present in $70 \%$ of both non-tumour and tumour sites. De Frietas et al. (2013) identified and quantified Candida on head and neck irradiated patients with two comparative elderly populations. Among the 92 patients surveyed, $51(55.4 \%)$ had scores classified as positive for Candida. Gender was not associated with Candida portability. Candida portability was significantly associated with the presence of candidiasis and xerostomic state. The isolates and definitive confirmed colonies were Candida albicans, $C$. dubliniensis, $C$. tropicalis, C. krusei, C. glabrata, C. parapsilosis, $C$. guilliermondii, $C$. lusitaniae, and $C$. kefyr. Among the species identified, $C$. albicans was the most frequent, followed by $C$. tropicalis, $C$. parapsilosis and $C$. glabrata. On multiple statistical models, only radiotherapy treatment was associated with positiveness to Candida. On the Contrary, $\mathrm{Hu}$ et al. 2013 used a high-throughput sequencing technique (pyrosequencing) to estimate the detailed diversity of plaque microbiota of irradiated patients. Streptococcus and other caries-related bacteria such as Veillonella and Actinomyces fluctuated significantly and accounted for a large proportion of the bacterial communities. These three genera interact with each other in the oral cavity, and they may play an important role in the development of dental caries. The Granulicatella was dramatically reduced in dental plaque after radiotherapy. Therefore, authors tempting to speculate that Granulicatella is unlikely to contribute to the pathogenesis of post-radiation diseases such as radiation caries. Derxia, which has also been found in tropical soils and Luteococcus, which were also isolated from human blood and the peritoneum (Collins et al. 2003) fluctuated differently, but little information about its pathogenicity in oral cavity is available so far. Other predominant genera such as Rothia, Prevotella, Capnocytophaga and Neisseria, might be involved in the susceptibility of an individual to periodontal disease (Ling et al. 2010). In contrast Schmidt et al. (2014) reported that in the cancer tissue samples Firmicutes (especially Streptococcus)

and Actinobacteria (especially Rothia) was significantly decreased relative to contralateral normal tissue samples from the same patient. In another study Devi and Singh (2014), reported that after standard radiotherapy, there was a profound shift in the oral microflora to predominance of acidogenic microbes, primarily Streptococcus mutans and Lactobacilli coincident with a decrease in salivary flora and an increase in caries risk. Dental caries in irradiated patients may develop rapidly as early as 3 months after radiotherapy. Henceforth, De Ryck et al. (2015) reported the potential role of the oral microbiota in radiotherapy-induced side effects like mucositis and performed band wise cluster analysis after Denaturing Gradient Gel Electrophoresis to gain insights into the microbial shifts that occurred during radiation therapy. Samples of the first weeks of irradiation clustered together and towards the end of the therapy the richness decreased ($14 \%$ ) and the oral microbial community became dominated by a small fraction of species. These studies reported here suggest that by monitoring the microbial shifts during radiation therapy, the role of the microbiota in disease initiation and development can be elucidated and treatment regimes can be adapted.

Further, Almståhl et al. (2015) investigated post radiotherapy effects after 3 years of irradiation and reported higher numbers and proportions of Lactobacilli, Candida albicans in the supragingival plaque. On the contrary higher numbers of enterococci in the vestibulum in the molar region and on the tongue, a lower total count and lower numbers of Streptococci, Streptococcus salivarius and Fusobacterium nucleatum on the tongue were observed. Although both stimulated and unstimulated salivary secretion rates increased over time, the proportion of microorganisms associated with oral health decreased, and microorganisms associated with oral disorders increased. Increased Lactobacilli and C. albicans 2 yrs post radiotherapy may reflect not only a reduced whole saliva flow rate, but also reduced buccal gland saliva and an acidic environment. In another study Ligtenberg and Almståhl (2015) reported that hyposalivation leads to changes in the oral microflora. In combination with a lower defense, this leads to a higher susceptibility to oral infections such as caries and mucosal infections. Gao et al. (2015) studied the variation in oral microflora of the subgingival plaque during and after radiotherapy using $16 \mathrm{~S}$ rDNA. A total of 120 genera were found; five genera (Actinomyces, Veillonella, Prevotella, Streptococcus, Campylobacter) were found in all the studied patients before and after radiotherapy. The richness and diversity of oral ecology decreased with increased radiation dose which was gradually restored with time. Zhang et al. (2015) isolated eleven genera of microbes (Streptococcus, Neisseria, Scardovia, Porphyromonas, Fusobacteria, Lautropia, Veillonella, Capnocytophaga, Rithia, Leptotrichia and Prevotella) and reported Streptococcus spp. and Neisseria spp. in more than $80 \%$ of samples. However, no clear relationship between the characteristics of patient salivary microbiota and radiation caries one year after intensity modulated radiation therapy (IMRT) was established. The study clearly suggested that

\section{Volume 6 Issue 12, December 2017}




\section{International Journal of Science and Research (IJSR) \\ ISSN (Online): 2319-7064}

Index Copernicus Value (2016): 79.57 | Impact Factor (2015): 6.391

salivary function in irradiated patients does not recover fully after 12-36 months, although the $\mathrm{pH}$ value and buffering capacity of saliva returns to normal after one year or more following intensity modulated radiation therapy. Further, it was concluded that population-based long term studies are required to reveal the factors for the absence of radiation caries. In a recent study, Schuurhuis et al. (2016) reported that different radiation treatments with intensity modulated radiation treatment to head and neck cancer patients result in different changes in the oral microflora with opportunistic pathogens such as Staphylococci, enteric rods and Candida sp. increasing in prevalence with or without chemotherapy, but not after surgical intervention. In another study Vanhoecke et al. (2016) reported the effect of irradiation on behavioral characteristics of oral microbial species in the context of mucositis particularly on growth and biofilm formation in different culture conditions. Biofilm formation of Klebsiella oxytoca and Candida glabrata was affected by irradiation and depended on the culturing conditions. Furthermore, irradiated Klebsiella. oxytoca microbes were found to be more virulent on Glabrata melonella larvae as compared to the non irradiated ones. Authors reported that low-dose irradiation could have an impact on functional characteristics of microbial species.

\section{Dental/Radiation caries}

It has always been a matter of debate whether radiation caries is due to a direct or indirect effect of irradiation on teeth, or due to oral microflora. The most threatening complication for the dentition, however, is radiation-related caries. Radiation caries is a highly destructive form of dental caries which has a rapid onset and progression (Karmiol and Walsh, 1975; Vissink et al., 2003). Dental caries may become evident as early as three months following the initiation of radiotherapy. In severe cases, a previously healthy dentition can be completely lost within a year (Dreizen et al., 1977). Early studies from the seventies and eighties emphasize on a correlation between the reduction of the amount of saliva, lower $\mathrm{pH}$ and growth of acidophilic organisms, which can indirectly lead to radiation caries (AlNawas and Grötz 2006). Both high consumption of short chain carbohydrates and reduced oral hygiene are known as promoting factors for radiation caries (Grötz et al. 2001). Similarly, Marcotte and Lavoie (1998) reported caries and periodontal diseases are associated with indigenous bacteria and identified the role of secretary immunoglobulin A (SIgA) in the control of the oral indigenous microbiota. In contrast Epstein et al. (1998) reported that patients, who had not experienced tooth decay for some time, might develop radiation caries when submitted to radiotherapy. The main factor for the development of such injuries is the decrease of saliva amount and its qualitative alterations. Besides, radiation has a direct effect on teeth, making them more susceptible to decalcification (Silverman, 1999). In another study reported (Otmani, 2007) changes in the chemical composition of saliva and increased amounts of cariogenic oral bacteria result in rapid decalcification of dental enamel.
Aggressive and extensive caries, commonly known as radiation caries, tends to spread to all dental surfaces, changing their translucency and colour. Radiation caries is not caused directly by irradiation, but results from the sequelae of xerostomia and a cariogenic shift in microflora. Other than xerostomia and hyposalivation which were among the most common treatment side effects on patients during and following radiotherapy treatment, the carious process causes increased friability and the breakdown of teeth (Tolentino et al. 2011). They are the result of radiationinduced damage to the salivary glands. Patients with chronic hyposalivation are at risk for demineralization and dental cavitation (dental caries), often presenting as a severe form of rapidly developing decay that results in loss of dentition. Usual post-radiation oral care which includes the use of fluoride, may decrease, but does not eliminate dental caries associated with radiation-induced hyposalivation (Deng et al., 2015). In a review article, Kaul et al. 2015 reported that changes in the chemical composition of saliva and increased amounts of cariogenic oral bacteria result in rapid decalcification of dental enamel. On the contrary Zhang et al. (2015) had reported previously that there was no clear relationship between high risk of developing radiation caries and the changes in the oral microbiota within the first year following radiotherapy. The salivary function and the salivary microbiota are correlated to the absence of radiation caries after one year of radiotherapy. Notably, authors did not detect any significant decrease in $\mathrm{pH}$ value and buffering capacity of the stimulated saliva when compared with normal values. Zhang et al. (2015) reported the quantity of Streptococcus mutans and Lactobacilli were same in both the radiation caries free patients and radiation caries patients. The results were in contradiction with previously published reports possibly because all the participants in their studies had not been treated by radiotherapy and had healthy salivary function and their data showed only a weak correlation between oral microbial diversity with the absence of radiation caries. It was concluded that population-based a long term study is required to reveal the factors for the absence of radiation caries. As mentioned earlier, radiation may permanently alter the quality and quantity of salivary flow. Saliva plays an integral role in the prevention of dental caries because with its protective action the cariogenic oral bacteria cannot colonize on the teeth. In the absence of a strict and meticulous preventive hygiene regimen, rampant caries typically results. After radiotherapy within three months carious lesions begin to appear and proceed rapidly to devastate the dentition. The key to managing this problem in patients likely to undergo radiotherapy is prevention. A thorough dental clinical examination including full mouth radiographs, diagnosis, and the treatment should be done before the start of radiotherapy. Addionally, a complete examination of the mucosa, dentition, and periodontium should also be done. After the radiotherapy special care of patients for dental hygiene, daily fluoride application, carbohydrate restriction and frequent dental follow up are essential.

Table 3: Summary of studies on Oral Microbiota modification after radiotherapy of patients with head and neck malignancies

\begin{tabular}{|c|c|c|c|c|}
\hline Study & No. of subjects & $\begin{array}{c}\text { Techniques } \\
\text { used }\end{array}$ & $\begin{array}{c}\text { Material } \\
\text { analyzed }\end{array}$ & Microorganisms reported/ Commentary \\
\hline Martin et al. & 31 patients were studied. & Microbiological & Saliva & Candida albicans and C. tropicalis were the principal yeasts \\
\hline
\end{tabular}

Volume 6 Issue 12, December 2017 


\section{International Journal of Science and Research (IJSR) \\ ISSN (Online): 2319-7064}

Index Copernicus Value (2016): 79.57 | Impact Factor (2015): 6.391

\begin{tabular}{|c|c|c|c|c|}
\hline 1981 & $\begin{array}{l}22 \text { with oral neoplasms and } \\
9 \text { with laryngeal neoplasms }\end{array}$ & Methods & & $\begin{array}{l}\text { isolated through out the period along with T glabrata and } \\
\text { Rhodotorula rubra. The number and types of fungi remain } \\
\text { high in both the groups of patients and persisted at higher } \\
\text { levels for 4-6 months after the treatment. }\end{array}$ \\
\hline $\begin{array}{l}\text { Brown et al. } \\
1978\end{array}$ & $\begin{array}{l}42 \text { head and neck cancer } \\
\text { patients } \\
36 \text { Post radiation therapy } \\
\text { patients }\end{array}$ & $\begin{array}{l}\text { Biochemical } \\
\text { tests }\end{array}$ & Saliva & $\begin{array}{l}\text { Post irradiation caries was associated with increased plaque } \\
\text { Lactobacillus sp, Candida } \mathrm{sp} \text {, and Streptococcus } \mathrm{sp} \text {. } \\
\text { Conversely, plaque Staphylococcus } \mathrm{sp} \text {, Streptococcus } \\
\text { salivarius, and Veillonella } \mathrm{sp} \text { were significantly higher in the } \\
\text { caries-inactive than in the caries-active group. }\end{array}$ \\
\hline $\begin{array}{c}\text { Kuten et al. } \\
1986\end{array}$ & 36 patients & $\begin{array}{l}\text { Microbiological } \\
\text { analysis }\end{array}$ & Saliva & $\begin{array}{l}\text { Decrease in salivary secretion is accompanied by rise in } \\
\text { salivary sodium concentration and in oral yeast flora. }\end{array}$ \\
\hline $\begin{array}{c}\text { Keene and } \\
\text { Fleming, } 1987\end{array}$ & $\begin{array}{l}68 \text { adult xerostomic } \\
\text { patients with head and } \\
\text { neck cancer }\end{array}$ & $\begin{array}{l}\text { Fluoride gels } \\
\text { analysis }\end{array}$ & Saliva & $\begin{array}{l}\text { The levels of Lactobacilli and Streptococcus mutans were } \\
\text { significantly elevated in all post radiotherapy patients. }\end{array}$ \\
\hline $\begin{array}{l}\text { Epstein et al. } \\
1998\end{array}$ & $\begin{array}{l}22 \text { cancer patients with } \\
\text { head and neck radiation }\end{array}$ & $\begin{array}{l}\text { Microbiological } \\
\text { Analysis }\end{array}$ & Saliva & $\begin{array}{c}\text { No significant changes in cariogenic oral flora were seen } \\
\text { during and early after radiation therapy, despite xerostomia. } \\
\text { However, colonization by Candida albicans increased } \\
\text { during radiation therapy. }\end{array}$ \\
\hline $\begin{array}{l}\text { Kamath et al. } \\
2002\end{array}$ & $\begin{array}{l}35 \text { patients with } \\
\text { oropharyngeal cancer and } \\
\text { fifteen controls were } \\
\text { included. }\end{array}$ & $\begin{array}{l}\text { Microbiological } \\
\text { analysis }\end{array}$ & $\begin{array}{l}\text { Swabs } \\
\text { from the } \\
\text { tonsillar } \\
\text { fossae. }\end{array}$ & $\begin{array}{c}\text { Streptococcus pneumoniae was significantly decreased at end } \\
\text { of irradiation, while there was an increase in Staphylococcus } \\
\text { aureus. Pseudomonas, Bacteroides and Candida species. } \\
\text { There was no change in culture and sensitivity pattern prior } \\
\text { to and after radiotherapy. }\end{array}$ \\
\hline $\begin{array}{l}\text { Tong et al. } \\
2003\end{array}$ & $\begin{array}{l}12 \text { Nasopharyngeal cancer } \\
\text { patients with equal number } \\
\text { of controls }\end{array}$ & $\begin{array}{l}\text { Biochemical } \\
\text { tests along with } \\
16 \text { S rDNA } \\
\text { sequencing } \\
\text { homology } \\
\text { analysis }\end{array}$ & Saliva & $\begin{array}{c}\text { S. mitis and S. salivarius } \\
\text { were the predominant non-mutans Streptococci in the } \\
\text { high-caries-risk oral flora following radiotherapy. }\end{array}$ \\
\hline $\begin{array}{l}\text { Stokman et al. } \\
2003\end{array}$ & $\begin{array}{c}65 \text { patients with malignant } \\
\text { tumour in head and neck } \\
\text { region out of which } 58 \\
\text { were evaluable }\end{array}$ & $\begin{array}{l}\text { Microbiological } \\
\text { methods }\end{array}$ & Saliva & $\begin{array}{c}\text { The presence of Candida species and aerobic Gram-negative } \\
\text { bacilli has no effect on the development and severity of } \\
\text { radiation-induced mucositis. }\end{array}$ \\
\hline Sharma 2005 & $\begin{array}{l}45 \text { patients with OSCC and } \\
229 \text { healthy controls }\end{array}$ & $\begin{array}{l}\text { Microbiological } \\
\text { methods }\end{array}$ & Saliva & $\begin{array}{c}\text { P. melaninogenica, } \\
\text { Leptotrichia buccalis, Capnocytophaga ochracea, } C \text {. } \\
\text { gingivalis, Eubacterium saburreum, and } S . \text { mitis were } \\
\text { significantly higher in radiotherapy patients than in controls. }\end{array}$ \\
\hline $\begin{array}{l}\text { Eliassonn et } \\
\text { al. } 2006\end{array}$ & $\begin{array}{l}10 \text { patients after } 3-5 \text { years } \\
\text { of RT with } 10 \text { control } \\
\text { participants }\end{array}$ & $\begin{array}{l}\text { Microbiological } \\
\text { analysis with } \\
\text { pH } \\
\text { measurement } \\
\text { using } \\
\text { microelectrodes }\end{array}$ & Saliva & $\begin{array}{c}\text { Compared with their controls, the irradiated group displayed } \\
\text { increased numbers of lactobacilli and Candida species and } \\
\text { reduced buffering capacity of saliva. }\end{array}$ \\
\hline $\begin{array}{l}\text { Srithavaj and } \\
\text { Thaweboon } \\
2006\end{array}$ & $\begin{array}{l}19 \text { children with } \\
\text { radiotherapy for } \\
\text { retinoblastoma and control } \\
\text { group of } 20 \text { healthy } \\
\text { children from a primary } \\
\text { school in Bangkok, } \\
\text { Thailand } \\
\end{array}$ & $\begin{array}{l}\text { Microbiological } \\
\text { Assay }\end{array}$ & Saliva & $\begin{array}{l}\text { The irradiated children showed abundance of Lactobacilli and } \\
\text { candida } s p \text {. as compared to healthy children. }\end{array}$ \\
\hline $\begin{array}{l}\text { Al Nawas and } \\
\text { Grotz } 2006\end{array}$ & $\begin{array}{c}22 \text { patients with squamous } \\
\text { cell carcinoma of head and } \\
\text { neck }\end{array}$ & $\begin{array}{l}\text { Molecular } \\
\text { biology using } \\
\text { DNA probes }\end{array}$ & Saliva & $\begin{array}{l}\text { The Lactobacilli counts varied from mean value of } 575 \mathrm{cfu} / \mathrm{ml} \\
\text { at first month to } 910 \mathrm{cfu} / \mathrm{ml} \text { at } 12 \mathrm{months} \text { whereas } \\
\text { Streptococci counts varied from } 680 \mathrm{cfu} / \mathrm{ml} \text { to } 1000 \mathrm{cfu} / \mathrm{ml} \text { at } \\
12 \text { months with borderline statistical significance. }\end{array}$ \\
\hline $\begin{array}{l}\text { Gaetti-Jardim } \\
\text { et al. } 2011\end{array}$ & $\begin{array}{l}50 \text { patients receiving } \\
\text { Radiotherapy }\end{array}$ & $\begin{array}{l}\text { Microbiological } \\
\text { growth on } \\
\text { specific media } \\
\text { along with PCR } \\
\text { assays using } \\
\text { specific primer } \\
\text { pairs }\end{array}$ & $\begin{array}{l}\text { Saliva, } \\
\text { mucosa } \\
\text { and } \\
\text { Biofilm } \\
\text { samples }\end{array}$ & $\begin{array}{l}\text { The most prevalent yeasts in patients submitted to } \\
\text { radiotherapy were Candida albicans, C. tropicalis, C. krusei, } \\
\text { C. glabrata and C. parapsilosis and bacteria were } \\
\text { Citrobacter, Enterobacter, Enterococcus, Klebsiella, Proteus, } \\
\text { and Pseudomonas. }\end{array}$ \\
\hline
\end{tabular}

\section{Conclusion}

Oral microbial flora beyond doubt, have a very important role to play in patients suffering with head and neck malignancies. A thorough understanding of the normal and altered microflora due to radiotherapy and the mechanism behind such population is of great significance it ameliorate the agony of patients with head and neck malignancies. The investigations of microbiota gene functions are required to better understand the impact of microbiota transformation during treatment of cancers. Continued surveillance of the oral cavity and early management of complications arising at later stages are of utmost importance in the long term care of

\section{Volume 6 Issue 12, December 2017}




\section{International Journal of Science and Research (IJSR) \\ ISSN (Online): 2319-7064 \\ Index Copernicus Value (2016): 79.57 | Impact Factor (2015): 6.391}

the patients receiving radiation treatment. A combination of enhancing radiotherapy safeguards, oral health instructions (clinicians should be aware of important microbial shifts and monitor the presence of pathogens to avoid more undesirable side effects), effective oral care and timely dental intervention may be essential to decrease oral sequelae and preventing microflora induced complications and thus increasing patients' quality of life.

\section{Conflicts of interest}

There are no conflicts of interest.

\section{References}

[1] Aas JA, Paster BJ, Stokes LN, Olsen I, Dewhirst FE. Defining the normal bacterial flora of the oral cavity. Journal of clinical microbiology. 2005 Nov 1;43(11):5721-32.

[2] Agarwal P, Upadhyay R, Agarwal A. Radiotherapy complications and their possible management in the head and neck region. Indian Journal of Dental Research. 2012 Nov 1;23(6):843.

[3] Almståhl A, Wikström M, Fagerberg-Mohlin B. Microflora in oral ecosystems and salivary secretion rates-A 3-year follow-up after radiation therapy to the head and neck region. Archives of oral biology. 2015 Sep 30;60(9):1187-95.

[4] Al-Nawas B, Grötz KA. Prospective study of the long term change of the oral flora after radiation therapy. Supportive care in cancer. 2006 Mar 1;14(3):291-6.

[5] Baskar R, Dai J, Wenlong N, Yeo R, Yeoh KW. Biological response of cancer cells to radiation treatment. Frontiers in Molecular Biosciences. 2014;1.

[6] Behl M, Manchanda AS, Sachdeva HS, Kaur T, Sarang S. Radiotherpay in oral cavity: consequences and current management regimes.. Journal of Advanced Medical and Dental Sciences Research| Vol. 2014 Oct;2(4).

[7] Bhatia R, Ichhpujani RL. Essentials of medical microbiology. Jaypee Broth. Med. Publ.; 1994.

[8] Brook I. Anaerobic infections in children. InHot topics in infection and immunity in children VII 2011 (pp. 117-152). Springer New York.

[9] Brown LR, Dreizen S, Daly TE, Drane JB, Handler S, Riggan LJ, Johnston DA. Interrelations of oral microorganisms, immunoglobulins, and dental caries following radiotherapy. Journal of dental research. 1978 Sep 1;57(9):882-93.

[10] Caufield PW, Dasanayake AP, Li Y, Pan Y, Hsu J, Hardin JM. Natural history of Streptococcus sanguinis in the oral cavity of infants: evidence for a discrete window of infectivity. Infection and immunity. 2000 Jul 1;68(7):4018-23.

[11] Collins MD, Hutson RA, Hoyles L, Falsen E, Nikolaitchouk N, Foster G. Streptococcus ovis sp. nov., isolated from sheep. International journal of systematic and evolutionary microbiology. 2001 May 1;51(3):1147-50.

[12] da Cunha SR, Ramos PA, Nesrallah AC, Parahyba CJ, Fregnani ER, Aranha AC. The Effects of Ionizing Radiation on the Oral Cavity. The journal of contemporary dental practice. 2014 Dec;16(8):679-87.
[13] de Freitas EM, Nobre SA, de Oliveira Pires MB, Faria RV, Batista AU, Bonan PR. Oral Candida species in head and neck cancer patients treated by radiotherapy. Auris Nasus Larynx. 2013 Aug 31;40(4):400-4.

[14] De Ryck T, Duprez F, Bracke M, Van de Wiele T, Vanhoecke B. Dynamic shifts in the oral microbiome during radiotherapy. Clinical research in infectious diseases. 2015;2(1).

[15] Deng J, Jackson L, Epstein JB, Migliorati CA, Murphy BA. Dental demineralization and caries in patients with head and neck cancer. Oral oncology. 2015 Sep 30;51(9):824-31.

[16] Devi S, Singh N. Dental care during and after radiotherapy in head and neck cancer. National journal of maxillofacial surgery. $2014 \mathrm{Jul} ; 5(2): 117$.

[17] Dewhirst FE, Chen T, Izard J, Paster BJ, Tanner AC, $\mathrm{Yu}$ WH, Lakshmanan A, Wade WG. The human oral microbiome. Journal of bacteriology. 2010 Oct 1;192(19):5002-17.

[18] Dreizen S, Brown LR, Daly TE, Drane JB. Prevention of xerostomia-related dental caries in irradiated cancer patients. Journal of Dental Research. 1977 Feb 1;56(2):99-104

[19] Eliasson L, Carlén A, Almståhl A, Wikström M, Lingström P. Dental plaque $\mathrm{pH}$ and micro-organisms during hyposalivation. Journal of dental research. 2006 Apr 1;85(4):334-8.

[20] Emidio TC, Maeda YC, Caldo-Teixeira AS, PuppinRontani RM. Oral manifestations of leukemia and antineoplastic treatment-a literature review (part II). Braz J Health. 2010;1:136-49.

[21] Epstein JB, Chin EA, Jacobson JJ, Rishiraj B, Le N The relationships among fluoride, cariogenic oral flora, and salivary flow rate during radiation therapy. Oral Surgery, Oral Medicine, Oral Pathology, Oral Radiology, and Endodontology. 1998 Sep 30;86(3):286-92.

[22] Epstein JB, Polsky B. Oropharyngeal candidiasis: a review of its clinical spectrum and current therapies. Clinical therapeutics. 1998 Feb 28;20(1):40-57.

[23] Gaetti-Jardim Júnior E, Ciesielski FI, Sousa FR, Nwaokorie F, Schweitzer CM, Avila-Campos MJ. Occurrence of yeasts, pseudomonads and enteric bacteria in the oral cavity of patients undergoing head and neck radiotherapy. Brazilian Journal of Microbiology. 2011 Sep;42(3):1047-55.

[24] Gao L, Hu Y, Wang Y, Jiang W, He Z, Zhu C, Ma R, Huang Z. Exploring the variation of oral microbiota in supragingival plaque during and after head-and-neck radiotherapy using pyrosequencing. Archives of oral biology. 2015 Sep 30;60(9):1222-30.

[25] Grötz KA, Riesenbeck D, Brahm R, Seegenschmiedt MH, Al-Nawas B, Dörr W, Kutzner J, Willich N, Thelen M, Wagner W. Chronische Strahlenfolgen an den Zahnhartgeweben ("Strahlenkaries") Klassifikation und Behandlungsansätze. Strahlentherapie und Onkologie. 2001 Jan 1;177(2):96104.

[26] Hu YJ, Wang Q, Jiang YT, Ma R, Xia WW, Tang ZS, Liu Z, Liang JP, Huang ZW. Characterization of oral bacterial diversity of irradiated patients by highthroughput sequencing. International journal of oral science. 2013 Apr 1;5(1):21-5.

\section{Volume 6 Issue 12, December 2017}




\section{International Journal of Science and Research (IJSR) \\ ISSN (Online): 2319-7064 \\ Index Copernicus Value (2016): 79.57 | Impact Factor (2015): 6.391}

[27] Kamath MP, Hegde MC, Sreedharan S, Salmi DK, Padmanabhan K. Radiotherapeutic effect on oropharyngeal flora in head and neck cancer. Indian Journal of Otolaryngology and Head and Neck Surgery. 2002 Apr 1;54(2):111-4.

[28] Karmiol M, Walsh RF. Dental caries after radiotherapy of the oral regions. The Journal of the American Dental Association. 1975 Oct 31;91(4):838-45.

[29] Kaul R, Angrish P, Arora K, Jain P. Dental complications of head and neck radiotherapy and their management: A review. Universal Research Journal of Dentistry. 2015 Sep 1;5(3):165.

[30] Keegan G. Antimicrobial bioadhesive polymer complexes for the oral cavity(Doctoral dissertation, GlaxoSmithKline). 2007.

[31] Keene HJ, Fleming TJ. Prevalence of caries-associated microflora after radiotherapy in patients with cancer of the head and neck. Oral Surgery, Oral Medicine, Oral Pathology. 1987 Oct 31;64(4):421-6.

[32] Könönen E. Development of oral bacterial flora in young children. Annals of medicine. 2000 Jan $1 ; 32(2): 107-12$.

[33] Kuten A, Ben-Aryeh H, Berdicevsky I, Ore L, Szargel R, Gutman D, Robinson E. Oral side effects of head and neck irradiation: correlation between clinical manifestations and laboratory data. International Journal of Radiation Oncology* Biology* Physics. 1986 Mar 1;12(3):401-5.

[34] Lalla RV, Bowen J, Barasch A, Elting L, Epstein J, Keefe DM, McGuire DB, Migliorati C, Nicolatou-Galitis O, Peterson DE, Raber-Durlacher JE. MASCC/ISOO clinical practice guidelines for the management of mucositis secondary to cancer therapy. Cancer. 2014 May 15;120(10):1453-61.

[35] Ligtenberg AJ, Almståhl A. Xerostomia and the oral microflora. InDry Mouth 2015 (pp. 81-101). Springer Berlin Heidelberg.

[36] Ling Z, Kong J, Jia P, Wei C, Wang Y, Pan Z, Huang W, Li L, Chen H, Xiang C. Analysis of oral microbiota in children with dental caries by PCR-DGGE and barcoded pyrosequencing. Microbial ecology. 2010 Oct 1;60(3):677-90.

[37] MacFarlane TW, Samaranayake LP. Oral ecosystem and dental plaque. Clinical Oral Microbiology. Editor: Sayer L. London: Wright. 1989.

[38] Marcotte H, Lavoie MC. Oral microbial ecology and the role of salivary immunoglobulin A. Microbiology and molecular biology reviews. 1998 Mar 1;62(1):71109.

[39] Marta GN, Silva V, de Andrade Carvalho H, de Arruda FF, Hanna SA, Gadia R, da Silva JL, Correa SF, Abreu $\mathrm{CE}$, Riera R. Intensity-modulated radiation therapy for head and neck cancer: systematic review and metaanalysis. Radiotherapy and Oncology. 2014 Jan 31;110(1):9-15.

[40] Martin MV, Al-Tikriti U, Bramley PA. Yeast flora of the mouth and skin uring and after irradiation or oral and laryngeal cancer. Journal of medical microbiology. 1981 Nov 1;14(4):457-67.

[41] Mathur VP, Dhillon JK, Kalra G. Oral health in children with leukemia. Indian journal of palliative care. 2012 Jan;18(1):12-18.
[42] McCarthy C, Snyder ML, Parker RB. The indigenous oral flora of man-I: The newborn to the 1-year-old infant. Archives of oral biology. 1965 Feb 28;10(1):6170.

[43] Meca LB, Souza FR, Tanimoto HM, Castro AL, Gaetti-Jardim Júnior E. Influence of preventive dental treatment on mutans streptococci counts in patients undergoing head and neck radiotherapy. Journal of Applied Oral Science. 2009;17(SPE):5-12.

[44] Möller P, Perrier M, Ozsahin M, Monnier P. A prospective study of salivary gland function in patients undergoing radiotherapy for squamous cell carcinoma of the oropharynx. Oral Surgery, Oral Medicine, Oral Pathology, Oral Radiology, and Endodontology. 2004 Feb 29;97(2):173-89.

[45] Najjar T, Rutner T, Schwartz RA. Bacterial mouth infections. Emedicine from WebMD. 2004.

[46] Otmani N. Oral and maxillofacial side effects of radiation therapy on children. Journal-Canadian Dental Association. 2007 Apr 1;73(3):257-61.

[47] Pushalkar S, Ji X, Li Y, Estilo C, Yegnanarayana R, Singh B, Li X, Saxena D. Comparison of oral microbiota in tumor and non-tumor tissues of patients with oral squamous cell carcinoma. BMC microbiology. 2012 Jul 20;12(1):1-15

[48] Ray-Chaudhuri A, Shah K, Porter RJ. The oral management of patients who have received radiotherapy to the head and neck region. British dental journal. 2013 Apr 27;214(8):387-93.

[49] Robins-Sadler G, Stoudt A, Fullerton JT, OberleEdwards LK. Managing the oral sequelae of cancer therapy. Medsurg Nursing. 2003 Feb 1;12(1):28.

[50] Rotimi VO, Duerden BI. The development of the bacterial flora in normal neonates. Journal of medical microbiology. 1981 Feb 1;14(1):51-62.

[51] Schmidt BL, Kuczynski J, Bhattacharya A, Huey B, Corby PM, Queiroz EL, Nightingale K, Kerr AR, DeLacure MD, Veeramachaneni R, Olshen AB. Changes in abundance of oral microbiota associated with oral cancer. PLoS One. 2014 Jun 2;9(6):1-12

[52] Schuurhuis JM, Stokman MA, Witjes MJ, Langendijk JA, van Winkelhoff AJ, Vissink A, Spijkervet FK. Head and neck intensity modulated radiation therapy leads to an increase of opportunistic oral pathogens. Oral Oncology. 2016 Jul 31;58:32-40.

[53] Sharma DC. Salivary bacteria linked to oral cancers. The Lancet Oncology. 2005 Aug 31;6(8):547.

[54] Silverman S. Oral cancer: complications of therapy. Oral Surgery, Oral Medicine, Oral Pathology, Oral Radiology, and Endodontology. 1999 Aug 31;88(2):122-6.

[55] Sonalika WG, Tayaar SA, Bhat KG, Patil BR, Muddapur MV. Oral microbial carriage in oral squamous cell carcinoma patients at the time of diagnosis and during radiotherapy-A comparative study. Oral oncology. 2012 Sep 30;48(9):881-6.

[56] Sonis ST, Costa Jr JW. Oral Complications of Radiotherapy. Holland-Frei Cancer Medicine, 6th edition. 2003

[57] Srinivasprasad V, Dineshshankar J, Sathiyajeeva J, Karthikeyan M, Sunitha J, Ragunathan R. Liaison between micro-organisms and oral cancer. Journal of 


\section{International Journal of Science and Research (IJSR) \\ ISSN (Online): 2319-7064 \\ Index Copernicus Value (2016): 79.57 | Impact Factor (2015): 6.391}

pharmacy \& bioallied sciences. 2015 Aug;7(Suppl 2):354-360

[58] Srithavaj T, Thaweboon S. Determination of oral microflora in irradiated ocular deformed children. Southeast Asian J Trop Med Public Health. 2006; 37(5): 991-995

[59] Stokman MA, Spijkervet FK, Burlage FR, Dijkstra PU, Manson WL, de Vries EG, Roodenburg JL. Oral mucositis and selective elimination of oral flora in head and neck cancer patients receiving radiotherapy: a double-blind randomised clinical trial. British journal of cancer. 2003 Apr 7;88(7):1012-6.

[60] Takeshita T, Yasui M, Tomioka M, Nakano Y, Shimazaki Y, Yamashita Y. Enteral tube feeding alters the oral indigenous microbiota in elderly adults. Applied and environmental microbiology. 2011 Oct 1;77(19):6739-45.

[61] Tolentino ED, Centurion BS, Ferreira LH, Souza AP, Damante JH, Rubira-Bullen IR. Oral adverse effects of head and neck radiotherapy: literature review and suggestion of a clinical oral care guideline for irradiated patients. Journal of Applied Oral Science. 2011 Oct;19(5):448-54.

[62] Tong HC, Gao XJ, Dong XZ. Non-mutans streptococci in patients receiving radiotherapy in the head and neck area. Caries research. 2003 Jun 3;37(4):261-6.

[63] Vanhoecke BW, De Ryck TR, Wiles S, Boterberg T, Van de Wiele T, Swift S. Low-dose irradiation affects the functional behavior of oral microbiota in the context of mucositis. Experimental Biology and Medicine. 2015 Jul 22: 241(1):60-70

[64] Vissink A, Jansma J, Spijkervet FK, Burlage FR, Coppes RP. Oral sequelae of head and neck radiotherapy. Critical Reviews in Oral Biology \& Medicine. 2003 May 1;14(3):199-212.

[65] Zhang J, Liu H, Liang X, Zhang M, Wang R, Peng G, $\mathrm{Li}$ J. Investigation of salivary function and oral microbiota of radiation caries-free people with nasopharyngeal carcinoma. PloS one. 2015 Apr $10 ; 10(4): 1-15$

Volume 6 Issue 12, December 2017

www.ijsr.net

Licensed Under Creative Commons Attribution CC BY 